\title{
DAMPAK UMK DAN PDRB TERHADAP PENGANGGURAN DI PULAU JAWA TAHUN 2015: ANALISIS SPASIAL EKONOMETRIK
}

\section{IMPACT OF UMK AND GRDP ON UNEMPLOYMENT IN JAVA ISLAND 2015: ECONOMETRIC SPATIAL ANALYSIS}

\author{
Beni Teguh Gunawan, Firdausi Nuzula \\ Pusat Penelitian dan Pengembangan, Kementerian Ketenagakerjaan RI \\ J1. Jendral Gatot Subroto Kav. 51, Jakarta Selatan, DKI Jakarta \\ beni.teguhg@gmail.com,firdausinuzula.02225@gmail.com
}

\begin{abstract}
ABSTRAK
Pengangguran, upah minimum dan pertumbuhan ekonomi menjadi komponen penting dalam pembangunan di suatu negara. Pada tingkatan lebih kecil, yaitu provinsi dan kabupaten/kota ketiga variabel tersebut menjadi sangat kompleks karena mempertimbangkan interaksi antar daerah. Paper ini bertujuan untuk melihat dampak UMK dan PDRB terhadap pengangguran khususnya di Pulau Jawa tahun 2015. Dampak yang dilihat mempertimbangkan adanya pengaruh spasial yang memungkinkan interaksi antar wilayah terjadi. Data yang digunakan adalah publikasi BPS dari masing-masing kabupaten/kota di Pulau Jawa untuk data PDRB dan pengangguran, sedangkan data UMK diperoleh melalui Kementerian Ketenagakerjaan. Analisis yang digunakan dalam paper ini adalah analisis spasial dengan menggunakan metode dependent variable lag, independent variable lag dan error lag. Hasil analisis empiris menunjukkan bahwa hanya variabel UMK yang berpengaruh signifikan terhadap pengangguran. Demikian pula hanya aspek spasial pada persamaan error lag yang signifikan.
\end{abstract}

Kata Kunci: UMK, PDRB, Pengangguran, Jawa, Spasial

\section{ABSTRACT}

Unemployment, minimum wages and economic growth become important components in a country's development. At a smaller level, namely the provinces and districts/cities, these three variables become very complex because they consider interactions between regions. This paper aims to look at the impact of MSE and GRDP on unemployment, especially in Java in 2015. The impact seen considers spatial influences that allow interaction between regions to occur. The data sources are from BPS especially for GDRP and unemployment in resident/city level data, the minimum wage data provided by Ministry of Manpower. This paper used spatial analysis econometric especially dependent variable lag, independent variable lag, and error lag. The results of empirical analysis show that only MSE variables have a significant effect on unemployment. Likewise, only the spatial aspects of the error lag equation are significant.

Keywords: Minimum Wage, GRDP, Unemployment, Java, Spatial

\section{PENDAHULUAN}

Indonesia merupakan sebuah negara yang sangat besar baik dari segi jumlah penduduk maupun angkatan kerja. Rilis dari BPS menunjukkan bahwa jumlah angkatan kerja di Indonesia pada tahun 2017 mencapai 128,06 juta jiwa. Dari jumlah tersebut jumlah pengangguran terbuka relatif rendah yakni 5,5 persen. Akan tetapi, salah satu permasalahan dari angkatan kerja tersebut adalah pengangguran terselubung yang relatif besar. Proporsi setengah pengangguran juga cukup besar, berdasarkan data BPS tahun 2017, angka setengah penganggur di Indonesia sebesar 7,55 persen. Dari jumlah tersebut, 10,52 persen tinggal di perdesaan. Jika ditinjau dari tingkat pendidikan, sebanyak 9,48 persen justru berasal dari pendidikan menengah dan 5,57 persen dari pendidikan tinggi. 
Apapun jenisnya, pengangguran selalu menjadi polemik yang sulit diatasi setiap rezim pemerintahan di negara manapun. Selain dapat berdampak pada faktor ekonomi pengangguran juga sering dikaitkan dengan kemiskinan (Fryer \& Fagan, 2001), kejahatan (Mauro \& Carmeci, 2007), dan bahkan gangguan kejiwaan (Weich \& Lewis, 1998). Pengangguran tidak hanya berdampak negatif pada jangka pendek perekonomian suatu negara. Perbandingan yang tidak seimbang antara jumlah pekerjaan yang tersedia dengan jumlah pencari kerja adalah salah satu penyebab tingginya pengangguran disamping ketidaksiapan para pencari kerja untuk memasuki dunia kerja. Faktor pertama akan menjadi fokus dalam paper ini, di mana pencari kerja yang sangat besar harus dihadapkan dengan terbatasnya jumlah lapangan kerja. Pencari kerja yang benar-benar mampu dan siaplah yang akan lolos dari seleksi alam. Teori ekonomi tenaga kerja mengatakan bahwa terdapat banyak hal yang mempengaruhi pengangguran.

Menurut Trimurti \& Komalasari (2014), pengangguran dapat ditimbulkan oleh perubahan pada pertumbuhan ekonomi, inflasi dan upah minimum. Demikian pula penelitianpenelitian lain di beberapa negara maju maupun negara berkembang yang umumnya memasukkan pengaruh upah minimum dan pertumbuhan ekonomi dalam variabel yang berpengaruh terhadap pengangguran (Card \& Krueger, 1994).

Penelitian-penelitian tersebut umumnya masih jarang yang memasukkan efek kewilayahan padahal masing-masing daerah memiliki karakteristik yang berbeda. Ramadhini, et al. (2019) menggunakan analisis spasial untuk menganalisis pengaruh jumlah pekerja, pendapatan daerah, dan UMK tehadap PDRB di Pulau Jawa pada tahun 2017. Hasilnya menunjukkan bahwa PDRB suatu daerah dipengaruhi oleh variabel-variabel tersebut secara signifikan. Penelitian ini akan berfokus pada pengaruh UMK dan PDRB terhadap pengangguran di level kabupaten/kota di Pulau Jawa tahun 2015. Alasan penggunaan tahun 2015 dalam analisis adalah secara kebijakan tahun 2015 adalah tahun terakhir pemberlakuan UMK berdasarkan KHL. Hal ini merupakan dampak dari pemberlakuan PP No.78 tahun 2015 tentang Pengupahan. PP tersebut menggunakan dasar penghitungan deterministik untuk penentuan upah minimum di suatu provinsi maupun kabupaten/kota.
Berdasarkan teori upah minimum, pada tingkat reservation wage tertentu keputusan individu untuk bekerja atau tidak sama kuat. Kondisi yang menggambarkan pasar kerja pada saat seseorang memutuskan untuk menjadi angkatan kerja akan menciptakan perubahan dalam pasar kerja yang membuat pasar kerja melakukan penyesuaian untuk memperoleh keseimbangan umum yang baru. Keseimbangan umum baru yang tercipta adalah bentuk gabungan keseimbangan dari sisi penawaran dan permintaan. Brochu \& Green (2013) memfokuskan pada analisis dampak upah minimum terhadap transisi pasar kerja dengan pendekatan permintaan menggunakan model Mortensen-Pissarides yang menggunakan pendekatan teori dari sisi permintaan.

Menurut asumsi neoklasikal, standar yang menggunakan asumsi pasar tenaga kerja yang homogen, kompetitif, dan lingkup pengaturan upah minimum yang berlaku menyeluruh pada semua kelompok pekerja (complete coverage). Jika upah minimum ditetapkan di atas nilai upah rata-rata pasar (above the market clearing wage), dampaknya akan mengurangi jumlah permintaan terhadap tenaga kerja oleh perusahaan-perusahaan dan pada akhirnya akan menurunkan jumlah tenaga kerja (Blanchard, Dell'Ariccia, \& Mauro, 2010). Jika diurai lebih eksplisit, pertambahan upah minimum dapat menambah lapangan kerja di satu sisi atau menyebabkan pemutusan hubungan kerja (PHK) disisi lain tergantung pada marginal product of labor (MPL), jika MPL dianggap lebih tinggi daripada pertambahan upah minimum, umumnya tidak menyebabkan PHK. Kemungkinan yang kedua dengan adanya PHK akan mengurangi tenaga kerja dalam pasar kerja, sehingga pengangguran akan meningkat.

Menurut Harfina (2009), secara umum, terjadinya pengangguran merupakan akibat dari ketidakseimbangnya antara penawaran dan permintaan tenaga kerja baik dari segi kuantitas maupun kualitas. Pengangguran merupakan dampak dari terbatasnya kesempatan kerja dan kurang sesuainya kualifikasi tenaga kerja dengan permintaan. Sesuai dengan konsep dan definisi Survei Angkatan Kerja Nasional yang diselenggarakan oleh Badan Pusat Statistik, penduduk dikelompokkan menjadi dua yaitu penduduk usia kerja dan bukan usia kerja. Penduduk usia kerja adalah penduduk yang berusia 15 tahun ke atas. Penduduk usia kerja dibedakan menjadi dua kelompok, yaitu angkatan kerja dan bukan angkatan kerja. 
Angkatan kerja meliputi penduduk berusia 15 tahun ke atas yang melakukan kegiatan bekerja, dan mereka yang tidak meniiliki pekerjaan atau tidak bekerja tetapi sedang mencari pekerjaan. Mereka yang mempunyai pekerjaan sementara tidak bekerja atau mereka yang sedang menyiapkan suatu usaha dan mereka yang tidak bekerja, atau sedang tidak mencari pekerjaan dan tidak yakin mendapatkan pekerjaan dikategorikan sebagai angkatan kerja. Kelompok yang bukan angkatan kerja adalah mereka yang masih sekolah, mengurus rumah tangga dan lain-lain, termasuk pensiunan dan cacat tubuh.

Badan Pusat Statistik mendefinisikan pengangguran terbuka adalah angkatan kerja yang tidak bekerja tetapi sedang mencari pekerjaan atau dapat dikatakan pengangguran adalah orang full timer mencari pekerjaan atau orang yang sedang mempersiapkan usaha atau mereka yang sudah mempunyai pekerjaan namun belum mulai bekerja. Selain itu, pengangguran terbuka adalah mereka yang tidak mencari pekerjaan karena merasa tidak mungkin mendapatkan pekerjaan. Ukuran yang digunakan adalah angka pengangguran terbuka, yaitu persentase angkatan kerja yang mencari pekerjaan terhadap angkatan kerja seluruhnya, konsep ini didasarkan pada pendekatan labourforce. Sebenarnya, pendekatan ini mempunyai kelemahan karena dari klasifikasi yang diajukan belum menggambarkan masalah ketenagakerjaan yang sebenamya. Angka pengangguran terbuka kurang tepat untuk menganalisis masalah ketenagakerjaan di negara berkembang, angka ini lebih sesuai untuk negara maju (Ananta, 1991).

Untuk mengatasi masalah ketenagakerjaan di Indonesia digunakan pendekatan pemanfaatan angkatan kerja yang diajukan oleh Sullivan \& Hauser (1979). Pendekatan ini melihat aspek jumlah jam kerja, besar pendapatan maupun aspek pendidikan terakhir yang ditamatkan. Pendekatan ini membagi angkatan kerja menjadi beberapa kelompok, yaitu angkatan kerja yang telah dimanfaatkan secara ekonomi dan mereka yang kurang dimanfaatkan. Berdasarkan pendekatan jumlah jam kerja apabila seseorang bekerja kurang dari sejumlah jam kerja normal akan menghasilkan, pekerja yang kurang dimanfaatkan. Sedangkan berdasarkan aspek pendidikan, akan diketahui apakah jenis pekerjaan yang dilakukan sesqai dengan pendidikan yang ditamatkan.
Di negara berkembang seperti Indonesia, masih banyak tenaga kerja yang belum dimanfaatkan secara memadai (underutilization) yang dikenal sebagai pengangguran tak kentara atau setengah pengangguran. Untuk menghitung tingginya tingkat setengah pengangguran Sullivan and Hauser (1979) mengemukan konsep "Labor Utilization Framework'. Setengah pengangguran merupakan refleksi dari penduduk yang bekerja tetapi tidak dimanfaatkan secara penuh. Pemanfaatan tidak penuh tersebut dapat didasarkan atas pendapatan,jam kerja dan kesesuaian pendidikan danjenis pekerjaan. Ketiga ukuran tersebut menggambarkan produktivitas angkatan kerja. Dengan kata lain setengah pengangguran adalah mereka yang bekerja denganjam kerja yang kurang, mereka yang bekerja dengan jam kerja cukup tetapi pendapatan kurang dan mereka yang walaupun jam kerja dan pendapatannya cukup tetapi tingkat pendidikannya lebih tinggi dari tingkat pendidikan yang dibutuhkan dalam pekerjaannya.

Pertumbuhan ekonomi diartikan sebagai kenaikan GDP tanpa memandang apakah kenaikan itu lebih besar atau lebih kecil dari tingkat pertumbuhan penduduk atau apakah perubahan struktur ekonomi terjadi atau tidak(Arsyad, 1997:13). Jika ingin mengetahui tingkat pertumbuhan ekonomi kita harus membandingkan pendapatan nasional dari tahun ke tahun. Dalam membandingkannya harus disadari bahwa perubahan nilai pendapatan yang nasional yang terjadi dari tahun ke tahun disebabkan oleh dua faktor yaitu perubahan tingkat kegiatan ekonomi dan perubahan hargaharga. Adanya pengaruh dari faktor yang kedua tersebut disebabkan oleh penilaian pendapatan nasional menurut harga yang berlaku pada tahun yang bersangkutan. Suatu perekonomian dikatakan mengalami pertumbuhan atau perkembangan jika tingkat kegiatan ekonomi yang dicapai lebih tinggi dari waktu sebelumnya.

Faktor-faktor yang mempengaruhi pertumbuhan ekonomi (Sukirno 1994:425):

a. Tanah dan kekayaan alam lain Kekayaan alam akan mempermudah usaha untuk membangun perekonomian suatu negara, terutama pada masa-masa permulaan dari proses pertumbuhan ekonomi.

b. Jumlah dan mutu penduduk dan tenaga kerja Penduduk yang bertambah akan 
mendorong maupun menghambat pertumbuhan ekonomi. Akibat buruk dari pertambahan penduduk kepada pertumbuhan ekonomi dapat terjadi ketika jumlah penduduk tidak sebanding dengan faktor-faktor produksi yang tersedia.

c. Barang-barang modal dan tingkat teknologi Barang-barang modal penting artinya dalam mempertinggi efisiensi pertumbuhan ekonomi, barang-barang modal yang sangat bertambah jumlahnya dan teknologi yang telah menjadi bertambah modern memegang peranan yang penting dalam mewujudkan kemajuan ekonomi yang tinggi.

d. Sistem sosial dan sikap masyarakat akan menentukan sampai dimana pertumbuhan ekonomi dapat dicapai.

e. Luas pasar sebagai sumber pertumbuhan Adam Smith telah menunjukkan bahwa spesialisasi dibatasi oleh luasnya pasar, dan spesialisasi yang terbatas membatasi pertumbuhan ekonomi.

Produk Domestik Regional Bruto (PDRB) Produk Domestik Regional Bruto (PDRB) adalah indikator ekonomi makro yang dapat memberikan gambaran tentang keadaan perekonomian suatu wilayah. Di dalam menghitung Produk Domestik Regional Bruto (PDRB) yang di timbulkan dari suatu region, ada 3 pendekatan yang digunakan yaitu:

a. PDRB menurut pendekatan produksi Merupakan jumlah nilai barang atau jasa akhir yang dihasilkan oleh berbagai unit produksi yang berada di suatu wilayah dalam jangka waktu tertentu.

b. PDRB menurut pendekatan pendapatan Merupakan balas jasa yang digunakan oleh faktor-faktor produksi yang ikut serta dalam proses produksi di suatu wilayah dalam waktu tertentu.

c. PDRB menurut pendekatan pengeluaran Merupakan semua komponen pengeluaran akhir seperti: pengeluaran konsumsi rumah tangga dan lembaga swasta nirlaba, konsumsi pemerintah, pembentukan modal tetap bruto, perubahan stok dan ekspor neto dalam jangka waktu tertentu.

Permasalahan dalam paper ini adalah bagaimana dampak upah minimum dan PDRB terhadap pengangguran di suatu wilayah. Dampak yang dilihat tidak hanya dari daerah itu sendiri tapi juga mempertimbangkan aspek kewilayahan. Pengangguran, PDRB dan UMK diduga sebuah hubungan variabel yang saling terkait satu sama lain. Paper ini bertujuan untuk melihat dampak UMK dan PDRB terhadap pengangguran khususnya di Pulau Jawa tahun 2015.

\section{METODE PENELITIAN}

\section{A. Data dan Variabel}

Paper ini membahas mengenai dampak upah minimum dan PDRB terhadap pengangguran di Pulau Jawa. Variabel-variabel utama UMK, PDRB dan pengangguran merupakan data amatan pada tingkatan kabupaten/kota pada tahun 2015. Data UMK bersumber dari Kementerian Ketenagakerjaan. UMK tahun 2015 ditetapkan pada bulan November 2014 melalui Peraturan Gubernur masing-masing wilayah. Penetapan UMK tahun 2015 masih mengikuti pola lama yang mempertimbangkan KHL. Sedangkan pola baru penetapan UMP dan UMK mulai tahun 2016 berbeda dengan pola sebelumnya. Pola baru merupakan kombinasi deterministik yang menghitung besaran UMK berdasarkan pertumbuhan ekonomi dan inflasi nasional. Pola baru ini diterapkan berdasarkan Peraturan Pemerintah No. 78 Tahun 2015 tentang Pengupahan. Pola upah minimum baru ini lebih memberikan kepastian bagi dunia usaha karena besarannya dapat diprediksi.

Data PDRB dan pengangguran bersumber dari BPS. Data PDRB yang digunakan merupakan PDRB berdasarkan harga konstan tahun 2010. Alasan penggunaan data PDRB berdasarkan harga konstan adalah karena diasumsikan semua daerah memiliki kondisi perekonomian yang sama pada tahun 2010 .

Data pengangguran diperoleh dari BPS yang bersumber dari Survei Angkatan Kerja Nasional (BPS) khususnya bulan Agustus tahun 2015. Sakernas dilakukan dua kali dalam satu tahun, yaitu Februari dan Agustus. Alasan penggunaan data Sakernas Agustus adalah karena Sakernas Agustus memiliki jumlah sampel yang lebih banyak dibandingkan dengan data Sakernas Februari, sehingga lebih representatif dalam mewakili populasi. Menurut Gunawan (2017) Desain pengambilan sampel dalam data Sakernas dibuat sedemikian rupa sehingga setiap responden dapat benar-benar mewakili karakteristik beberapa individu. Selain itu, Sakernas Februari hanya digunakan untuk mengestimasi tingkatan provinsi $(5.000$ blok sensus atau 50.000 rumah tangga) sedangkan 
Sakernas Agustus digunakan untuk estimasi kabupaten/kota $(5.000$ blok sensus ditambah 15.000 blok sensus).

\section{B. Analisis Deskriptif}

Analisis yang digunakan dalam paper ini adalah analisis deskriptif dan kuantitatif. Baik analisis deskriptif dan kuantitatif akan menggunakan perangkat lunak Stata MP 16 dan Microsoft Excel. Analisis deskriptif akan digunakan untuk melihat persebaran UMK, PDRB dan pengangguran di masing-masing kabupaten/kota. Hasil antara analisis deskriptif akan dibandingkan dengan analisis kuantitatif untuk melihat dampak spasial UMK dan PDRB terhadap pengangguran.

\section{Spasial Ekonometrik (Spatial Auto Regression/SAR)}

Model regresi SAR merupakan perluasan dari model regresi linier yang menyertakan dampak daerah terdekat, variabel independent daerah sekitar serta error dari daerah sekitar pula. Dikatakan dalam jargon spasial, model dapat dependen lag spasial) dan $\varepsilon$ adalah istilah kesalahan acak.

Model SARerr memiliki bentuk berikut:

$Y=X \beta+\varepsilon ; \varepsilon=\lambda W \varepsilon+\xi, \varepsilon \sim N(0, \sigma 2) \ldots$

di mana $\varepsilon$ adalah istilah kesalahan acak di mana $\lambda$ adalah koefisien autoregresi spasial, $\mathrm{W} \varepsilon$ mewakili struktur spasial (W) dalam istilah kesalahan $(\varepsilon)$ dan $\xi$ adalah istilah kesalahan independen setelah memperhitungkan hubungan spasial.

Indeks Moran digunakan untuk menentukan ketergantungan spasial residual model regresi. Persamaan ini digunakan untuk menghitung Moran's I:

$I=\frac{n}{\sum_{i=1}^{n}\left(X_{i}-\bar{X}\right)^{2}} \frac{\sum_{i=1}^{n} \sum_{j=1}^{n} W_{i j}\left(X_{i}-\bar{X}\right)\left(X_{j}-\bar{X}\right)}{\sum_{i=1}^{n} \sum_{j=1}^{n} W_{i j}}$

di mana $\mathrm{n}$ adalah jumlah pengamatan, $\mathrm{X}$ adalah nilai residual model untuk setiap titik pengambilan sampel, $\mathrm{X}^{-}$adalah rata-rata residu dan $\mathrm{W}_{\mathrm{ij}}$ adalah matriks bobot. Matriks bobot berisi lag spasial dari variabel hasil, lag spasial kovariat, dan error spasial autoregresif.

Model regresi spasial digunakan untuk mendeteksi faktor-faktor yang secara spasial. Secara teoritis, model autoregresi spasial (SAR) menambahkan istilah autokorelasi spasial dalam model standar regresi kuadrat terkecil biasa (OLS), di mana kedekatan lokasi pengambilan sampel ditentukan oleh matriks bobot spasial (W). Model SAR umumnya mengambil dua bentuk, model lag spasial (SARlag) di mana istilah autokorelasi spasial dikaitkan dengan variabel respons dan model error spasial (SARerr) yang memperhitungkan tren spasial dengan memasukkan proses autoregresif dalam istilah kesalahan. SARlag memiliki formula sebagai berikut:

$Y=X \beta+\rho W Y+\varepsilon, \varepsilon \sim N(0, \sigma 2) \ldots$

Dimana $X$ adalah variabel independen, $\beta$ adalah koefisien regresi, $\rho$ adalah koefisien autoregresi, WY menyatakan autokorelasi spasial dalam variabel respon Y (variabel

spasial kontiguitas berbasis jarak digunakan dalam analisis ini. Jarak ambang untuk menghindari pembentukan pulau dihitung dengan jarak Euclidean antara titik pengambilan sampel. Jarak ambang minimum untuk protokol pengambilan sampel saat ini adalah 4,0 m.

\section{HASIL DAN PEMBAHASAN}

\section{A. Analisis Deskriptif}

Pulau Jawa adalah pulau terbesar ke-13 di dunia dengan luas wilayah $138.793,6 \mathrm{~km}^{2}$ dengan populasi mencapai $1.317 \mathrm{orang} / \mathrm{km}^{2}$. Pulau Jawa terdiri dari 6 Provinsi yaitu Banten, DKI Jakarta, Jawa Barat, Jawa Tengah, DI Yogyakarta, dan Jawa Timur dengan total 119 kabupaten/kota. Grafik 1 menunjukkan rata-rata PDRB pada masing-masing provinsi pada tahun 2015. DKI Jakarta menjadi provinsi dengan PDRB tertinggi mencapai Rp. 242.863.200.000.000 Jawa Barat dan Banten memilki PDRB yang hampir sama yaitu berkisar 46 triliun rupiah. Sedangkan PDRB terendah dipegang oleh DI Yogyakarta. 
Vol. 15 No. 1, Edisi Januari - Juni 2020 ISSN : $2722-8770$

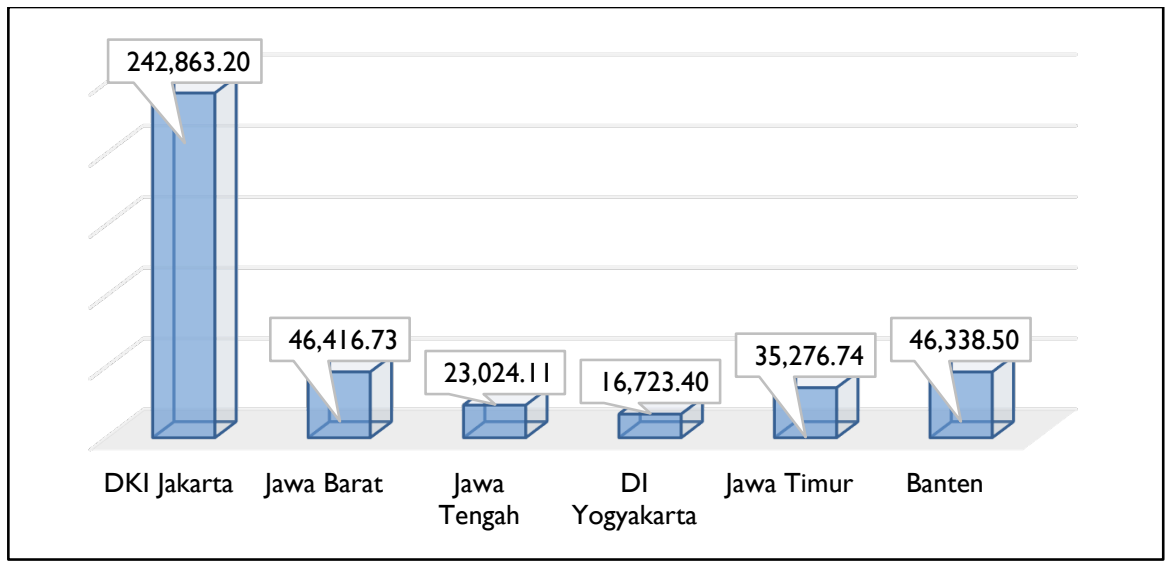

Gambar 1: Grafik Rata-rata PDRB (dalam miliar rupiah)

Jika ditinjau dari rata-rata UMK, DKI Jakarta juga masih menjadi yang tertinggi. Jakarta adalah satu-satunya provinsi yang menerapkan kebijakan satu upah minimum, yaitu hanya tingkatan provinsi. Hal ini tentu berbeda dengan provinsi lain yang menerapkan
UMK hingga tingkatan kabupaten/kota. Provinsi Jawa Tengah dan DI Yogyakarta memilikirata-rata UMK terendah jika dibandingkan daerah lain. Sedangkan Banten berada di urutan kedua setelah DKI Jakarta.

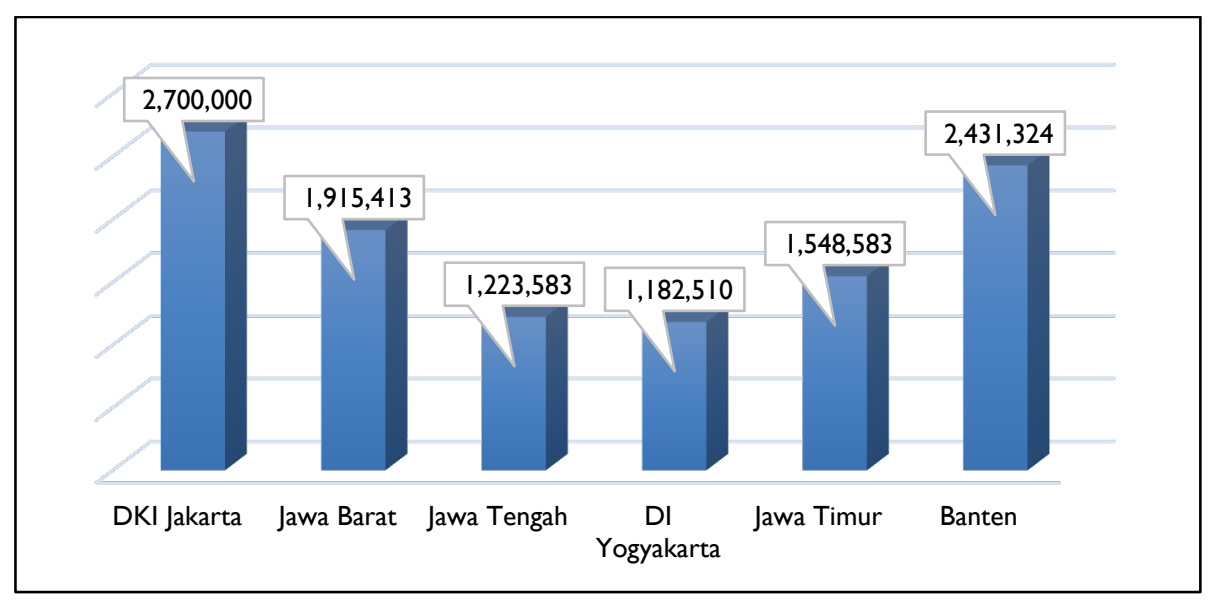

Gambar 2: Grafik Rata-rata Upah Minimum Provinsi (dalam rupiah)

Konsentrasi industri juga berpengaruh terhadap besaran upah minimum ini. Seperti yang diketahui, Jabodetabek adalah Kawasan yang bertumpu pada sektor industri dan jasa. Sedangkan di tengah dan timur Pulau Jawa umumnya masih menjadi kawasan pertanian. Jika ditinjau dari rata-rata pengangguran,
Banten menjadi provinsi yang memiliki rata-rata pengangguran tertinggi. Berdasarkan data, pada tahun 2015 rata-rata pengangguran di Banten sebesar 10,05 persen, sementara Jawa Barat dan DKI Jakarta berturut-turut 8,56 persen dan 6,82 persen. 


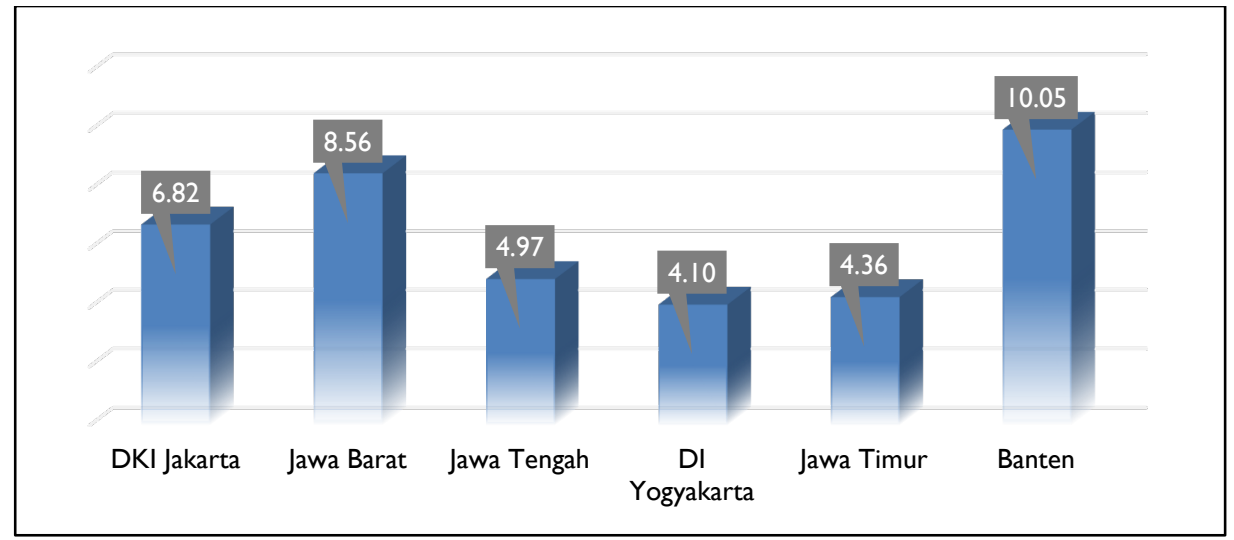

Gambar 3: Grafik Rata-rata Persentase Pengangguran Menurut Provinsi

Hingga tahun 2015, terdapat sebanyak 119 kabupaten/kota yang ada di Pulau Jawa. Kabupaten/kota termuda adalah Pangandaran yang dibentuk sejak tahun 2012. Kabupaten Pangandaran merupakan pemekaran dari
Kabupaten Ciamis. Sedangkan provinsi termuda di Pulau Jawa adalah Banten yang berdiri sejak tahun 2000. Provinsi Banten sendiri merupakan pemekaran dari Provinsi Jawa Barat.

Tabel 1: Hasil Analisis Deskriptif

\begin{tabular}{|r|l|r|r|r|r|}
\hline No & Variabel & Rata-rata & Standar Deviasi & \multicolumn{1}{l|}{ Terendah } & \multicolumn{1}{l|}{ Tertinggi } \\
\hline 1 & PDRB (miliar rupiah) & 44.616 .09 & 67.470 .12 & 2.624 & 354.882 \\
\hline 2 & UMK (rupiah) & 1.635 .893 & 595.969 .7 & 1.100 .000 & 2.957 .450 \\
\hline 3 & Pengangguran (persen) & 6,07 & 2,72 & 0,97 & 14,8 \\
\hline
\end{tabular}

Berdasarkan PDRB, kabupaten/kota di Pulau Jawa rata-rata memiliki PDRB sebesar 44,616 triliun rupiah. PDRB terendah berada di Kota Banjar Provinsi Jawa Barat dengan nilai PDRB sebesar 2,624 triliun rupiah. Sementara PDRB tertinggi dipegang oleh Kota Jakarta Pusat dengan PDRB sebesar 354,882 triliun rupiah. UMK Kabupaten Karawang menjadi UMK tertinggi di Pulau Jawa pada tahun 2015, dengan nilai Rp. 2.957.450, sedangkan UMK terendah dimiliki oleh Kabupaten Banyumas dengan nilai Rp.1.100.000. Jika dilihat dari persentase penganggur, Kabupaten Serang dan Pacitan adalah dua sisi yang bertentangan.
Kabupaten Pacitan dengan tingkat penganggur terendah sedangkan Kabupaten Serang dengan yang tertinggi, masing-masing berturut-turut 0,97 persen dan 14,8 persen.

Pola PDRB tahun 2015 menunjukkan bahwa konsentrasi perekonomian di Pulau Jawa ada di sekitar Jawa Barat sebelah utara, Jabodetabek dan Banten sebelah utara. Di sebelah timur potensi perekonomian ada di ujung utara Gresik hingga ke Malang, baik wilayah kota maupun kabupaten. Sedangkan di wilayah Jawa Tengah dan DIY cenderung memiliki perekonomian yang kurang baik dibandingkan sisi barat dan timur Jawa.

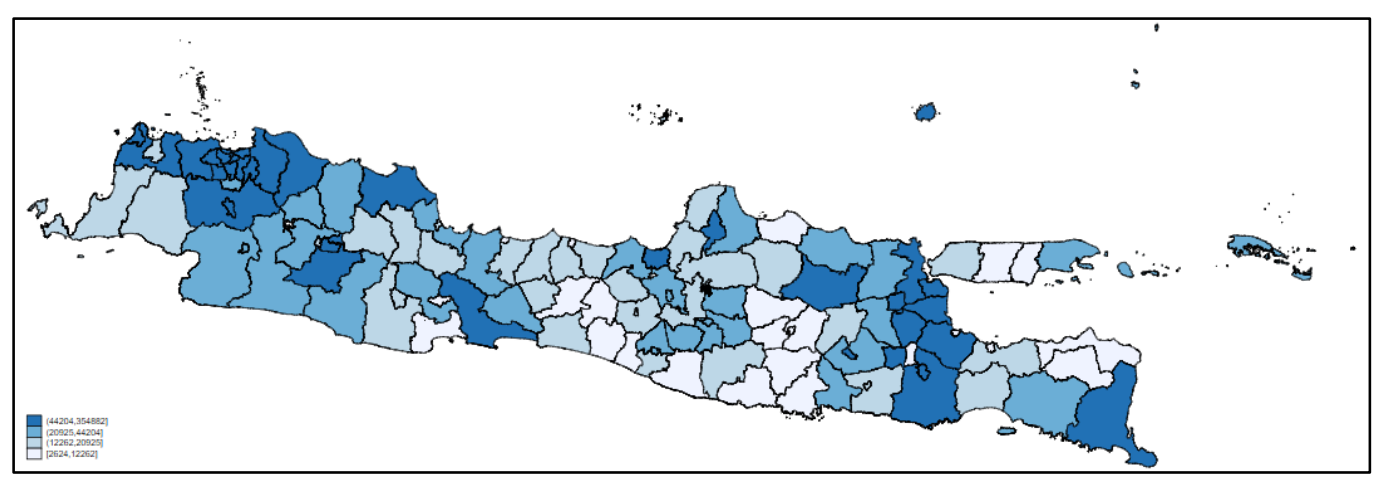

Gambar 4: Sebaran PDRB Tahun 2015 Menurut Harga Konstan 2010 di Pulau Jawa 
Gambar 4 menunjukkan bahwa spasial memberikan pengaruh terhadap perekonomian daerah. Wilayah yang berdekatan memiliki tingkat PDRB yang hampir sama, yaitu di wilayah Jabodetabek, dan Jawa Timur yang cenderung maju. Jika dilihat Jabodetabek hingga Banten sebelah utara merupakan motor perekonomian di Pulau Jawa karena konsentrasi industri ada di wilayah ini. Sedangkan Gerbang Kertasusila hingga Malang di Jawa Timur juga terkenal dengan kejayaan industrinya di timur Jawa. Jika dihubungkan dengan UMK, pola perekonomian di kabupaten/kota memiliki keseragaman. Wilayah barat dan timur pulau Jawa memiliki tingkat UMK yang secara nominal meninggalkan wilayah tengah.

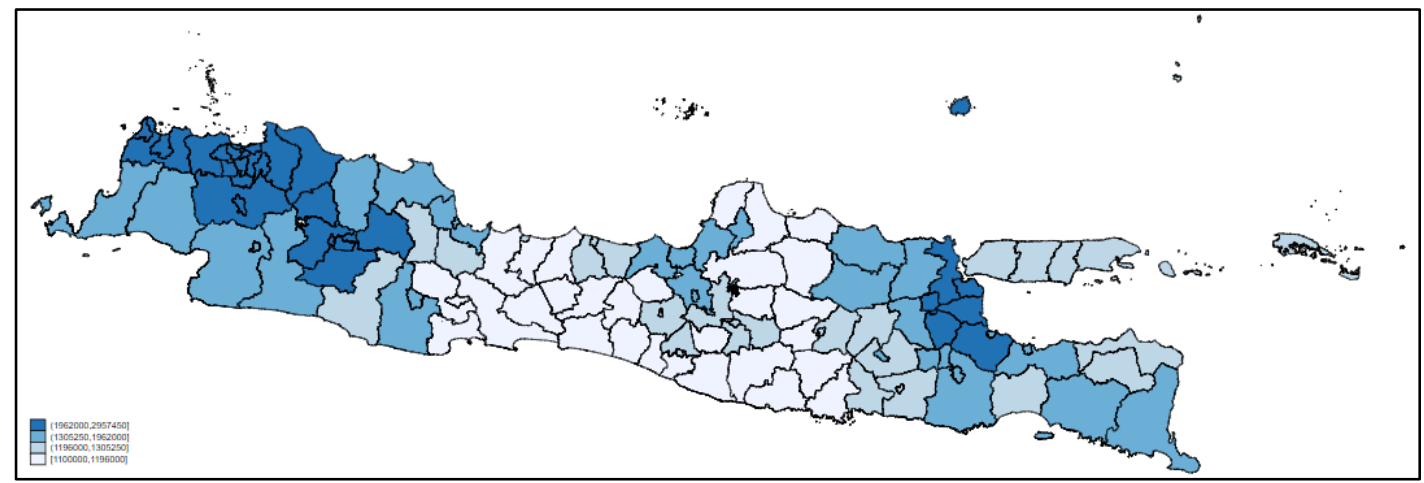

Gambar 5: Sebaran UMK Tahun 2015 di Pulau Jawa

Disparitas perekonomian cukup terlihat pada wilayah Jawa ini. Meskipun demikian, jika dibandingkan dengan UMK, tingkat PDRB jauh lebih merata. Perekonomian sudah bergerak berpindah dari wilayah dengan UMK tinggi ke UMK rendah. Sehingga dari Gambar 1 dan Gambar 2 perekonomian cenderung bergerak dari sisi barat dan sisi timur ke sisi tengah. Pada akhirnya perekonomian akan merata ke seluruh pulau Jawa, sedangkan UMK masih memiliki lag. Dugaan ini cukup beralasan, mengingat dukungan infrastruktur di Pulau Jawa sudah baik dibandingkan wilayah Indonesia lainnya.

Jika UMK dan PDRB cenderung berkaitan, di mana UMK bergerak lebih lambat dibandingkan dengan PDRB, maka pola pengangguran cenderung tidak berkaitan dengan merata di sisi tengah Pulau Jawa. Kemungkinan pergerakan UMK mengikuti pergerakan perekonomian, karena pengusaha cenderung akan

keduanya. Bagian barat Pulau Jawa yang memiliki tingkat PDRB dan UMK yang relatif tinggi dibandingkan dengan daerah lain justru memiliki pengangguran yang paling tinggi pula. Pola industri di Jawa Barat, Banten, dan DKI Jakarta memiliki efektivitas penyerapan tenaga kerja yang berbeda dengan sisi timur Pulau Jawa. Gerbang Kertasusila yang memiliki PDRB hampir setara dengan Jabodetabek, Banten dan Jabar justru memiliki tingkat pengangguran yang kecil, hampir sama dengan Jawa Tengah dan DI Yogyakarta.

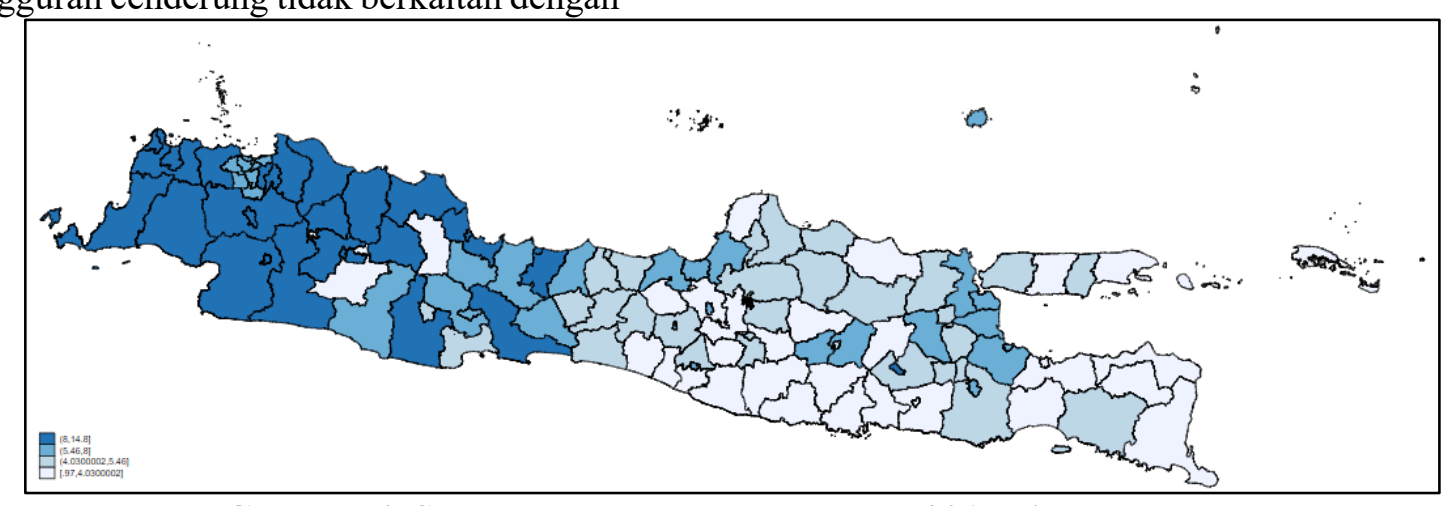

Gambar 6: Sebaran Pengangguran Tahun 2015 di Pulau Jawa

Keterkaitan UMK, PDRB dan pengangguran semakin terlihat anomali sisi ujung timur Pulau Jawa yaitu Kabupaten
Banyuwangi. Kabupaten Banyuwangi yang memiliki PDRB tinggi di satu sisi dan UMK yang berada di rata-rata bawah di Jawa Timur 
justru memiliki tingkat pengangguran yang rendah. Pola perekonomian di Kabupaten Banyuwangi terkenal dengan industri pariwisata, dan pertaniannya. Selain itu, kebijakan pimpinan daerah juga berpihak terhadap para pelaku industri kecil (Meranti, 2015). Model inklusivitas pada perekonomian di Banyuwangi ini diyakini adalah model terbaik dari pembangunan di suatu daerah.

\section{B. Analisis Empiris}

Analisis inferensia menggunakan SAR dengan dependent lag menunjukkan bahwa pengangguran dipengaruhi oleh UMK, di mana setiap kenaikan UMK sebesar satu persen akan meningkatkan pengangguran sebesar 4,9 persen. Pada model ini variabel PDRB tidak berpengaruh terhadap pengangguran. Sedangkan pada perspektif spasial, dampak spasial dari penganguran juga tidak signifikan. Uji serentak memperlihatkan bahwa secara keseluruhan model ini signifikan dengan $\mathrm{R}$ square sebesar 31,82 persen. Dari impact langsung menunjukkan bahwa model lag variabel dependen pengangguran di suatu wilayah dipengaruhi oleh UMK daerah itu sendiri, sementara pengaruh pengangguran dan PDRB dari daerah lain tidak signifikan.

Tabel 2: Hasil SAR dengan Dependent Lag

\begin{tabular}{lrrrrrr}
\hline \multicolumn{1}{c}{ UN } & Coef. & \multicolumn{1}{c}{ Std.Err. } & \multicolumn{1}{c}{$\mathrm{z}$} & $\mathrm{P}>\mathrm{z}$ & [95\%Conf. & Interval] \\
\hline UN & & & & & & \\
$\log \mathrm{UMK}$ & 4.919 & 0.855 & 5.76 & 0 & 3.244 & 6.594 \\
$\operatorname{logPDRB}$ & -0.054 & 0.292 & -0.19 & 0.853 & -0.627 & 0.518 \\
$\quad$ cons & -63.355 & 10.683 & -5.93 & 0 & -84.293 & -42.417 \\
W & & & & & & \\
UN & -0.043 & 0.096 & -0.45 & 0.654 & -0.232 & 0.146 \\
\hline
\end{tabular}

Tabel 3: Hasil Impact dengan Dependent Lag

\begin{tabular}{rrrrrrr}
\hline & $\mathrm{dy} / \mathrm{dx}$ & Std.Err. & $\mathrm{z}$ & $\mathrm{P}>\mathrm{z}$ & {$[95 \%$ Conf. } & Interval $]$ \\
\hline Direct & 4.920 & 0.855 & 5.75 & 0 & 3.243 & 6.596 \\
& -0.054 & 0.292 & -0.19 & 0.853 & -0.627 & 0.518 \\
Indirect & -0.156 & 0.341 & -0.46 & 0.647 & -0.826 & 0.513 \\
\multirow{4}{*}{ Total } & 0.002 & 0.009 & 0.2 & 0.842 & -0.015 & 0.019 \\
& 4.764 & 0.86 & 5.54 & 0 & 3.078 & 6.449 \\
& -0.053 & 0.284 & -0.18 & 0.853 & -0.609 & 0.504 \\
\hline
\end{tabular}

Pada analisis dengan independent lag, hasilnya hampir sama dengan persamaan yang menyertakan dependent lag, di mana pengangguran dipengaruhi oleh UMK, di mana setiap kenaikan UMK sebesar satu persen akan meningkatkan pengangguran sebesar 5,15 persen. Pada model ini variabel PDRB juga tidak berpengaruh terhadap pengangguran. Demikian pula pada aspek spasial, pengaruhnya juga tidak signifikan. Uji serentak memperlihatkan bahwa secara keseluruhan model ini signifikan dengan $\mathrm{R}$ square sebesar 32,31 persen. Dari impact langsung menunjukkan bahwa model lag variabel independen pengangguran di suatu wilayah dipengaruhi oleh UMK daerah itu sendiri, sementara pengaruh pengangguran dan PDRB dari daerah lain tidak signifikan.

Tabel 4: Hasil SAR dengan Independent Lag

\begin{tabular}{|c|c|c|c|c|c|c|}
\hline UN & Coef. & Std.Err. & $\mathrm{z}$ & $\mathrm{P}>\mathrm{Z}$ & [95\%Conf. & Interval] \\
\hline UN & & & & & & \\
\hline $\log \mathrm{UMK}$ & 5.157 & 1.001 & 5.15 & 0 & 3.195 & 7.119 \\
\hline $\log P D R B$ & 0.039 & 0.298 & 0.13 & 0.896 & -0.545 & 0.622 \\
\hline cons & -67.468 & 13.16 & -5.13 & 0 & -93.262 & -41.674 \\
\hline
\end{tabular}


Vol. 15 No. 1, Edisi Januari - Juni 2020 ISSN : 2722 - 8770

\begin{tabular}{lrrrrrr} 
W & & & & & & \\
$\log \mathrm{UMK}$ & 0.38 & 0.486 & 0.78 & 0.434 & -0.572 & 1.332 \\
$\log \mathrm{PDRB}$ & -0.582 & 0.686 & -0.85 & 0.396 & -1.926 & 0.761 \\
\hline
\end{tabular}

Tabel 5: Hasil Impact dengan Independent Lag

\begin{tabular}{rrrrrr}
\hline $\mathrm{dy} / \mathrm{dx}$ & Std.Err. & $\mathrm{z}$ & $\mathrm{P}>\mathrm{z}$ & {$[95 \%$ Conf. } & Interval] \\
\hline Direct 5.157 & 1.001 & 5.15 & 0 & 3.195 & 7.119 \\
0.039 & 0.298 & 0.13 & 0.896 & -0.545 & 0.622 \\
Indirect 0.289 & 0.369 & 0.78 & 0.434 & -0.434 & 1.011 \\
-0.442 & 0.521 & -0.85 & 0.396 & -1.462 & 0.578 \\
Total 5.445 & 1.236 & 4.41 & 0 & 3.023 & 7.868 \\
-0.403 & 0.542 & -0.74 & 0.456 & -1.465 & 0.658 \\
\hline
\end{tabular}

Pada analisis dengan error lag, hasilnya hampir sama dengan persamaan yang menyertakan dependent lag dan independent lag, di mana pengangguran hanya dipengaruhi oleh UMK. Setiap kenaikan UMK sebesar satu persen akan meningkatkan pengangguran sebesar 4,6 persen. Pada model ini variabel PDRB juga tidak berpengaruh terhadap pengangguran. Perbedaan pada model ini adalah pengaruh spasial dari error signifikan. Uji serentak memperlihatkan bahwa secara keseluruhan model ini signifikan dengan $R$ square sebesar 31,31 persen. Dari impact langsung menunjukkan bahwa model lag variabel error pengangguran di suatu wilayah hanya dipengaruhi oleh UMK daerah itu sendiri, sementara pengaruh pengangguran dan PDRB dari daerah lain tidak signifikan. Hal ini menunjukkan konsistensi dampak antara variabel independent terhadap dependen, di mana hasil dari ketiga metode menunjukkan bahwa pengangguran hanya dipengaruhi oleh UMK.

Tabel 6: Hasil SAR dengan Error Lag

\begin{tabular}{lrrrrrr}
\hline \multicolumn{1}{c}{ UN } & Coef. & Std.Err. & \multicolumn{1}{c}{$\mathrm{z}$} & $\mathrm{P}>\mathrm{z}$ & {$[95 \%$ Conf. } & Interval $]$ \\
\hline UN & & & & & & \\
$\operatorname{logUMK}$ & 4.679 & 0.978 & 4.79 & 0 & 2.763 & 6.596 \\
$\log$ PDRB & 0.086 & 0.228 & 0.38 & 0.706 & -0.36 & 0.532 \\
$\quad$ cons & -61.295 & 13.081 & -4.69 & 0 & -86.934 & -35.657 \\
W & & & & & & \\
e.UN & 0.801 & 0.091 & 8.84 & 0 & 0.623 & 0.979 \\
\hline
\end{tabular}

Tabel 7: Impact dengan Error Lag

\begin{tabular}{|c|c|c|c|c|c|c|}
\hline \multicolumn{2}{|c|}{$\mathrm{dy} / \mathrm{dx}$} & \multirow{2}{*}{$\begin{array}{r}\text { Std.Err. } \\
0.978\end{array}$} & \multirow{2}{*}{$\frac{\mathrm{z}}{4.79}$} & \multirow{2}{*}{$\begin{array}{ll}\mathrm{P}>\mathrm{Z} & \\
& 0\end{array}$} & \multirow{2}{*}{$\frac{[95 \% \text { Conf. }}{2.763}$} & \multirow{2}{*}{$\frac{\text { Interval] }}{6.596}$} \\
\hline Direct & 4.679 & & & & & \\
\hline & 0.086 & 0.228 & 0.38 & 0.706 & -0.36 & 0.532 \\
\hline Indirect & 0 & & (omitted) & & & \\
\hline & 0 & & (omitted) & & & \\
\hline Total & 4.679 & 0.978 & 4.79 & 0 & 2.763 & 6.596 \\
\hline & 0.086 & 0.228 & 0.38 & 0.706 & -0.36 & 0.532 \\
\hline
\end{tabular}




\section{Pembahasan}

Jika dilihat dari ketiga model tersebut menunjukkan bahwa pengaruh spasial tidak ada untuk kasus hubungan pengangguran dan PDRB. Sedangkan variabel UMK berpengaruh meskipun kecil. Pengaruh spasial dari wilayah terdekat juga tidak signifikan. Artinya perekonomian, pengangguran dan UMK di masing-masing wilayah merupakan dampak dari daerah itu sendiri dan tidak ada pengaruh dari daerah lain. Interaksi antar wilayah lemah jika melihat hasil dari analisis empiris. Hal ini terjadi kemungkinan karena data yang digunakan adalah cross sectional sehingga tidak dapat diamati selama periode waktu yang berbeda. Idealnya ketiga variabel tersebut memang saling berpengaruh dengan mempertimbangkan lag waktu. Artinya pengangguran suatu wilayah tidak langsung dipengaruhi oleh pertumbuhan ekonomi dan UMK di daerah yang sama dan waktu yang sama. Pengangguran umumnya dipengaruhi oleh kedua variabel tersebut saat t$1, \mathrm{t}-2$, atau lebih lama lagi.

Menurut Kurniawati (2018), UMK berdampak positif terhadap employment di sektor formal dan berdampak negatif terhadap employment di sektor informal ketika ketergantungan antar daerah (unit spasial) diperhitungkan dalam model. Hasil ini sejalan dengan hipotesis yang diusulkan dalam pasar tenaga kerja monopsony. Kenaikan 100\% upah minimum riil dapat meningkatkan employment di sektor formal sebesar $0.41 \%-0.47 \%$ (cateris paribus). Disisi lain, kenaikan $100 \%$ upah minimum dapat mengurangi employment di sektor informal sebesar $0,22 \% 0,35 \%$ (cateris paribus). Hasil dari studi ini berbeda dengan studi-studi sebelumnya yang menganalisis dampak upah minimum terhadap employment di Indonesia yang mayoritas menunjukkan dampak negatif kenaikan upah minimum terhadap employment di sektor formal. Dari studi ini dapat dikatakan bahwa ketika pasar tenaga kerja antar daerah tidak diasumsikan saling bebas, maka kebijakan upah minimum yang ditetapkan oleh pemerintah tidak selamanya berdampak buruk terhadap employment di sektor formal. Hasil dari penelitian ini sejalan dengan penelitian sebelumnya yang dilakukan oleh Magruder (2013) yang juga menemukan dampak positif kenaikan upah minimum terhadap employment. Hasil penelitian ini menunjukkan adanya indikasi bahwa pasar tenaga kerja di Pulau Jawa mengikuti model pasar tenaga kerja Monopsony. Oleh karena itu, pemerintah perlu mempertimbangkan kondisi tersebut dan berhati-hati ketika akan mengambil kebijakan terkait ketenagakerjaan di Pulau Jawa.

Menurut Vidyattama (2013), ada indikasi bahwa ketimpangan antar wilayah di Indonesia semakin tinggi, pertumbuhan yang tinggi di Jakarta dan daerah-daerah penyangganya tidak mampu diikuti oleh daerah-daerah lain. Sebaliknya, perubahan angka Indeks Pembangunan Manusia untuk Indonesia menunjukkan tingkat yang hampir setara antar daerah, walaupun kecepatannya menurun. Efek spasial memang kemungkinan berdampak signifikan, akan tetapi, tidak dapat dilihat dalam jangka pendek.

Selain itu, faktor geografis juga menjadi salah satu penentu besar kecilnya interaksi antar wilayah. Wilayah di Pulau Jawa antara barat, tengah dan timur juga cenderung memiliki karakteristik yang berbeda. Sebagai contoh di Jawa bagian barat. Jabodetabek, Banten bagian utara dan Karawang adalah daerah pesisir yang bertumpu pada sektor industri dan jasa. Modernisasi di kawasan ini jauh lebih tinggi dibandingkan dengan bagian selatan, seperti Banten selatan, Tasikmalaya, dan Sukabumi. Daerah-daerah bagian selatan cenderung tumbuh sendirian tanpa interaksi dengan daerah lain. Atau secara mendekat dengan daerah pertumbuhan lain seperti Bandung. Hal ini terjadi mengingat secara geografis, wilayahwilayah ini "terbelah" oleh Gunung Salak, Gunung Pangrango, dan Gunung Cikuray. Hal ini tentu akan berdampak pada sisi spasial kedua Kawasan.

Demikian pula dengan Jawa bagian tengah dan bagian timur. Di Jawa bagian tengah, sisi tengah juga dipenuhi oleh wilayah dengan kontur dataran tinggi yang cenderung menyekat akses utara-selatan. Adanya barisan gununggunung seperti Slamet, Sundoro, Sumbing, Merbabu dan Merapi menjadi salah satu aspek penting pertumbuhan dan interaksi kedua sisi wilayah.

Lalu bagaimana dengan Jawa bagian timur? Wilayah ini memiliki topografi yang lebih menantang. Wilayah tapal kuda hampir dipenuhi gunung-gunung yang menghambat akses perekonomian masyarakat. Pusat pertumbuhan di Jawa Timur berada di wilayah Gerbang Kertasusila (Gresik, Bangkalan, Mojokerto, Surabaya, Sidoarjo dan Lamongan) dan Malang Raya. Padahal seperti yang diketahui, Malang Raya dikelilingi oleh pegunungan, bahkan 
wilayah tapal kuda yang ingin ke Malang harus memutar hingga ke Pasuruan. Jawa Timur memiliki satu hal positif dibandingkan dengan daerah barat dan tengah Pulau Jawa mengingat sebagian besar gunungnya terkonsentrasi di sisi selatan. Dengan demikian, Gerbang Kertasusila dapat menjadi poros pertumbuhan yang mudah diakses dari sisi utara dan barat dan sebagian selatan provinsi.

Aspek lain yang juga mempengaruhi interaksi antar daerah adalah ketersediaan infrastruktur jalan. Tidak dapat dipungkiri bahwa dengan dibukanya akses jalan tol trans Jawa telah meningkatkan kemudahan rantai pasok logistik, utamanya di Pulau Jawa itu sendiri. Tonggaknya adalah saat beroperasinya tol Cipali (Cikopo-Palimanan) yang menjadi ruas tol terpanjang di Indonesia dengan panjang 116 kilometer. Tol Cipali resmi dibuka pada tanggal 13 Juni 2015, disusul dengan ruas-ruas lain hingga saat ini telah tersambung hingga Jawa bagian timur. Dalam teori pertumbuhan endogenous, infrastruktur merupakan salah satu investasi untuk mencapai tingkat pertumbuhan yang konvergen. Transmisinya adalah infrastruktur dapat menstimulasi pertumbuhan regional dan mengurangi dampak relative spasial (Romer, 2012). Meskipun dampaknya tidak dapat dilihat secara langsung dalam jangka pendek, infrastruktur juga dapat meningkatkan pendapatan per kapita (Prasetyo, Priyarsono, \& Mulatsih, 2013).

Faktor ketiga yang mungkin berpengaruh adalah etnis. Menurut Muller (2016) polarisasi etnis di Indonesia masih sangat tinggi. Artinya etnis-etnis tersebut masih senang hidup berkelompok dengan etnisnya sendiri. Hal ini memiliki dampak yang sangat luas mencakup dampak ekonomi dan kesejahteraan. Meskipun kebenarannya masih diragukan terlebih untuk wilayah Pulau Jawa hampir seluruh etnisnya telah berbaur. Akan tetapi, menarik untuk diteliti lebih lanjut mengenai dampak polarisasi etnis di Indonesia terhadap perekonomian. Beberapa etnis juga terkenal dengan tradisi merantaunya, misalnya Minang, Madura dan Batak.

Menurut Pratikto (2012) variabel budaya memiliki peranan yang cukup signifikan dalam mendorong pertumbuhan ekonomi suatu negara. Apabila dikaitkan dengan Indonesia maka diperlukan pemimpin yang sangat kuat untuk dapat memimpin Indonesia, karena tingkat heterogenitas masyarakat Indonesia. Hal ini berdampak pada tingginya biaya transaksi yang ditanggung oleh masyarakat karena adanya perbedaan budaya tersebut. Sebenarnya Indonesia sebagai bangsa sudah memiliki nilainilai luhur yang dapat digunakan untuk mendorong perbaikan norma sosial dan ekonomi, seperti yang tercantum di dalam Pancasila. Akan tetapi, karena pengalaman pada masa Orde Baru, yaitu Pancasila hanya sebatas pada tataran teoretis, tetapi tidak pada implementasinya, maka terjadi skeptisisme di kalangan masyarakat akan nilai-nilai luhur tersebut. Oleh karena itu, diperlukan pemimpin yang sangat kuat, agar implementasi nilai-nilai luhur tersebut dapat dilakukan. Hal itu penting karena dari pembahasan di atas, terlihat pentingnya nilai-nilai luhur yang terkandung di dalam Pancasila, seperti toleransi, keadilan, kebersamaan, dan sebagainya dalam mendorong pertumbuhan ekonomi karena dapat mengurangi biaya transaksi yang terjadi.

Faktor etnis dapat direduksi dengan pembentukan daerah-daerah pertumbuhan baru. Daerah-daerah pertumbuhan baru ini akan menjadi faktor penarik dari berbagai kelompok masyarakat sebagaimana konsep ekonomi regional. Konsep dalam ekonomi regional adalah sebuah daerah-daerah pertumbuhan baru akan menimbulkan spillover effect. Konsep ini telah banyak dianut oleh beberapa negara, diantaranya Amerika Serikat dengan Silicon Valley, India dengan Bengaluru dan China dengan Beijing dan Shanghai-nya. Sebenarnya Indonesia telah mencanangkan pusat-pusat pertumbuhan baru dalam Kawasan Ekonomi Khusus (KEK), Kawasan Industri (KI) hingga Kawasan Berikat (KB). Hanya saja hingga saat ini Kawasan-kawasan tersebut belum mampu memberikan dampak nyata terhadap pertumbuhan.

Dari sisi ketenagakerjaan, interaksi antar wilayah juga sangat penting. Salah satu keuntungannya adalah adanya kesetaraan upah antar wilayah. Kawasan Jabodetabek sebagai salah satu kawasan dengan interaksi spasial yang tinggi memiliki UMK yang hampir setara. Menurut Melo \& Graham (2009), aglomerasi dapat meningkatkan produktivitas, di mana pengurangan jarak tempuh pekerja setengahnya akan meningkatkan upah per jam hingga 1 persen, atau secara numerik, pengurangan 5 kilometer jarak tempuh pekerja akan meningkatkan upah per jam sebesar 1,19 persen. 


\section{KESIMPULAN}

Pada tahun yang sama, UMK, pengangguran dan PDRB memiliki pengaruh yang cenderung anomali antara pengamatan visual dan empiris. Pengangguran hanya dipengaruhi oleh upah minimum dari ketiga model dependent lag, independent lag, maupun error lag. Demikian pula dampak spasial untuk masing-masing model tidak signifikan kecuali pada model error lag. Hal ini terjadi kemungkinan karena data yang digunakan adalah cross sectional sehingga tidak dapat diamati selama periode waktu yang berbeda. Idealnya ketiga variabel tersebut memang saling berpengaruh dengan mempertimbangkan lag waktu. Artinya pengangguran suatu wilayah tidak langsung dipengaruhi oleh pertumbuhan ekonomi dan UMK di daerah yang sama dan waktu yang sama. Pengangguran umumnya dipengaruhi oleh kedua variabel tersebut saat $\mathrm{t}-1, \mathrm{t}-2$, atau lebih lama lagi.

Selain itu ada beberapa alasan mengapa dampak spasial antara UMK dan PDRB terhadap pengangguran kecil atau hampir tidak ada. Kondisi geografis, ketersediaan infrastruktur hingga kemungkinan adanya pengaruh sosial budaya diduga juga turut berpengaruh terhadap pengaruh spasial ini.

Pemerintah disarankan untuk meninjau kembali konsep-konsep Kawasan pertumbuhan untuk meningkatkan interaksi antar wilayah. Dari sisi ketenagakerjaan, semakin tinggi interaksi spasial akan menurunkan kesetaraan upah antar wilayah.

\section{DAFTAR PUSTAKA}

Ananta, A. (1991). Beberapa Skenario Ketenagakerjaan Indonesia 1990: Suatu Pendekatan Baru. Lembaga Demografi UI.

Blanchard, O., Dell'Ariccia, G., \& Mauro, P. (2010). Rethinking Macroeconomic Policy. Rethinking Macroeconomic Policy. https://doi.org/10.5089/9781455224982.0 04.a001

Brochu, P., \& Green, D. A. (2013). The impact of minimum wages on labour market transitions. Economic Journal, 123(573), $1203-1235$.

https://doi.org/10.1111/ecoj.12032

Card, D., \& Krueger, A. B. (1994). Minimum wages and employment: a case study of the fast-food industry in New Jersey and Pennsylvania. American Economic

Review. https://doi.org/10.2307/2118030

Fryer, D., \& Fagan, R. (2001). Poverty and Unemployment. In Poverty and Psychology (pp. 87-101). https://doi.org/http://dx.doi.org/10.1007/9 78-1-4615-0029-2 5

Gunawan, B. T. (2017). PARADOKS KEWIRAUSAHAAN DI INDONESIA, SEBUAH PELUANG ATAU KETERPAKSAAN? STUDI EMPIRISMENGGUNAKAN DATA SAKERNAS TAHUN 2017. Jurnal Ketenagakerjaan.

Harfina, D. (2009). FAKTOR-FAKTOR YANG MEMPENGARUHI PENGANGGURAN TERSELUBUNG DI PERDESAAN JAWA TENGAH. Jurnal Kependudukan Indonesia.

Kurniawati, A. (2018). DAMPAK UPAH MINIMUM TERHADAP EMPLOYMENT: PENDEKATAN DIFFERENCE IN SPATIAL DIFFERENCE. Jurnal Ketenagakerjaan, 13(2).

Mauro, L., \& Carmeci, G. (2007). A poverty trap of crime and unemployment. Review of Development Economics, 11(3), 450462. https://doi.org/10.1111/j.14679361.2006.00350.x

Melo, P. C., \& Graham, D. J. (2009). Agglomeration Economies and Labour Productivity: Evidence from Longitudinal Worker Data for GB's Travel-to-Work Areas. SERC DISCUSSION PAPER 31, 31.

Meranti, I. (2015). Implikasi Kerjasama ASEAN-China Free Trade Area (ACFTA) terhadap Kinerja UMKM dan Kesejahteraan Pelaku UMKM di Kabupaten Banyuwangi. Economic: Journal of Economic and Islamic, 5(2).

Muller, C. (2016). Ethnic inequality and community activities in Indonesia. WIDER Working Paper.

Prasetyo, B. A., Priyarsono, D. S., \& Mulatsih, S. (2013). Infrastructure, economic growth and inequality in Indonesia land borders. Economic Journal of Emerging Markets. https://doi.org/10.20885/ejem.vol5.iss2.art 3

Pratikto, A. (2012). Pengaruh Budaya Terhadap Kinerja Perekonomian. Buletin Studi 
Ekonomi, 17(2).

Ramadhini, F., Djuraidah, A., \& Hamim, A. (2019). Spatial Autoregressive Regression Modeling with Heteroskedasticity Using Bayesian Approach on GRDP of Java, 4531, 152-160.

Romer, D. (2012). Advanced Macroeconomics, 4th edition 1. New York.

https://doi.org/10.1017/CBO97811074153 24.004

Trimurti, C. P., \& Komalasari, Y. (2014). Determinants of Unemployment : Empirical Evidences from 7 Province in Indonesia. Scientific Research Journal (SCIRJ).

Vidyattama, Y. (2013). Regional convergence and the role of the neighbourhood effect in decentralised Indonesia. Bulletin of Indonesian Economic Studies. https://doi.org/10.1080/00074918.2013.80 9841

Weich, S., \& Lewis, G. (1998). Poverty, Unemployment, and Common Mental Disorders: Population Based Cohort Study. BMJ (Clinical Research Ed.), 317(7151), 115-119.

https://doi.org/10.1136/bmj.317.7151.115 